\title{
Implementation of Quizziz as a Pretest and Post-Test to Evaluate the Effectiveness of Small Group Learning
}

\author{
Prema Hapsari Hidayati ${ }^{1}$, Ratih Natasha ${ }^{1}$, Shofiyah Latief ${ }^{1}$, Nasruddin MA ${ }^{1}$, \\ Syarifuddin Wahid ${ }^{1}$
}

\author{
IMedical Faculty of Indonesian Moslem University \\ "Corresponding author: PremaHapsariHidayati@gmail.com
}

\begin{abstract}
Background and aims: Since the Indonesia Covid-19 pandemic spread out in March 2020, the online learning method was applied in a professional medical program, and we started to use "Quizziz," an educational game online. The study aimed to evaluate Small Group Learning activity's effectiveness using "Quizziz" as pre-test and post-test.

Methods: This research was quasi-experimental one group pre-posttest design, involving 107 medical professional students of Indonesian Muslim university enrolled in SGL activity as an enrichment program before entering clinical departments in November 2020. The "Quizziz" was done before and after the SGL activity and statistically analyzed the result. The students were also asked to answer some survey questions about Quizziz performance.

Result: In this research, we found the mean of Quizziz pre SGL score was 54,93 (SE $\pm 1,448$ ), and the mean of Quizziz post SGL score was 88,64 (SE $\pm 1,141)$. Because both data Quizziz pre and post SGL scores were normal distributions, we compared both statistically using t-paired student test. We found significantly different with $p$-value $<0,001$. The survey result confirmed $88,3 \%$ of the student said that The Quizziz's question was in line with SGL content, 87,9\% of students felt that The Quizziz improved their concentration, and 85,3\% reported that The Quizziz helped them to understand SGL's subject.

Conclusions: Small Group learning activity in medical profession program was very effective in improving student knowledge when evaluated with the Quizziz application
\end{abstract}

Keywords: SGL, The Quizziz, a medical student.

\section{INTRODUCTION}

Medical education in Indonesia consists of the academic stage and the professional stage. According to the university's standard, medical students must complete 144 credits at the academic stage to obtain an undergraduate medical degree. The student should learn about primary medical science, normal organ physiology, disease pathomechanism, and disease treatment in this stage. While in the professional stage, medical students should practice the knowledge they already had in the stage before in real condition with a real patient. They should learn how to make a precise diagnosis through a good anamnesis, an adequate physical examination, choose and perform laboratory tests or other supporting examination and then give appropriate treatment. Good analytical thinking is also needed to achieve this goal. [1]

Unfortunately, many medical professional program students have experienced difficulties transforming their knowledge into a skill they should perform. So, we conduct an activity assisting a student in reviewing and 
refreshing the knowledge about diseases studied in a particular clinical department called Small Group Learning (SGL). In this activity, medical professional students are given a brief review of diseases before they entered rotation in a particular clinical department. SGL has already been running for almost five years in Universitas Muslim Indonesia at medical faculty and seems to have a beneficial effect. However, an evaluation is still needed from time to time to assess SGL activities' effectiveness in increasing student knowledge.

After Covid19 struck the world in November 2019 and especially Indonesia in March 2020, there was a change in teaching and learning methods to become an online system. SGL activities are also carried out online using the Zoom meeting and Quizziz application before and after the SGL activity. Quizziz is a game-based educational online application designed to make users feel that studying is fun. By using Quizizz, students can do exercises on their electronic devices.[2] Unlike other educational apps, Quizizz has game characteristics such as avatars, themes, memes, and music to keep users entertained in the learning process. Quizizz also allows students to compete with each other and motivates them to learn.[3]

There was some publication about implementing the "Quizziz" application at all education levels to evaluate teaching and learning activities. These studies include a student from elementary school until university stage involving different faculty such as mathematics, language, and physics.[4][5] However, there is no research on Quizziz implementation in the medical professional program student yet. So, we are interested in conducting one. In this study, we would like to compare the Quizziz result as a pre-test and post-test to evaluate the SGL effectivity.

Table 1. Quizziz score distribution

\begin{tabular}{|l|r|lr|}
\hline $\begin{array}{l}\text { Quizziz } \\
\text { score }\end{array}$ & $\begin{array}{l}\text { Pre Tes } \\
\text { (n MPPD) }\end{array}$ & $\begin{array}{l}\text { Post Tes } \\
\text { (n MPPD) }\end{array}$ \\
\hline$<25$ & 1 & & 0 \\
\hline $26-50$ & 39 & 0 \\
\hline $51-75$ & 47 & 22 \\
\hline $76-100$ & 20 & 85 \\
\hline
\end{tabular}

\section{METHODS}

This research was a quasi-experimental one-group pre-test-post test design with total sampling technic. We enrolled 107 medical professional education students who took part in the SGL activity in November 2020.[6] First, the participants underwent a pre-test and post-test by Quizziz application before and after the SGL activity. When students start to join quizziz, the questions and answers were randomized. Thus, there were no same questions among students. The score was given based on accuracy and speed. If the answer was correct, they gained 600 points and $0-400$ points based on speed when the question timer was turned on or 1000 points if turned off. But if the answer was incorrect, they gained no score at all.[7] Apart from that, the SGL participants also filled out a survey about Quizziz implementation.

All data were analyzed using descriptive statistics and a paired t-test to evaluate the correlation between pre and post-test values.

\section{RESULTS}

There were 107 students included in this study, with $22 \%$ male and $78 \%$ female. The age range of participants was between $22-24$ years old. The mean pre-test value was 54.93 ( $\mathrm{SE} \pm 1.448)$, and the mean post-test value was 88.64 ( $\mathrm{SE} \pm 1.141)$. Since the data result was normally distributed, we continued to analyze with a paired T-test, and the result of $\mathrm{p}$-value was $<0.001$. The results showed $88,3 \%$ of Medical Professional Students stated that the Quizziz's questions were relevant to the SGL's subject. The results consisted of $87.9 \%$ of students indicating that quizziz improved their concentration, and $85.3 \%$ of students confirmed that Quizziz helped them to comprehend SGL's subject.

Table 2. Mean of quizziz score and p-value $p$

\begin{tabular}{|lll|ll|l|}
\hline \multicolumn{2}{|l|}{ Mean pre-test } & \multicolumn{2}{|l|}{ Mean post } & $\begin{array}{l}\text {-test } \\
\text { p-value }\end{array}$ \\
\hline $\begin{array}{l}54.93 \\
1.448)\end{array}$ & $\left(\begin{array}{lll}\mathrm{SE} & \pm & \left.\begin{array}{l}88.64 \\
1.141\end{array}\right)\end{array} \quad(\mathrm{SE} \quad \pm\right.$ & $<0,001$ \\
\hline
\end{tabular}




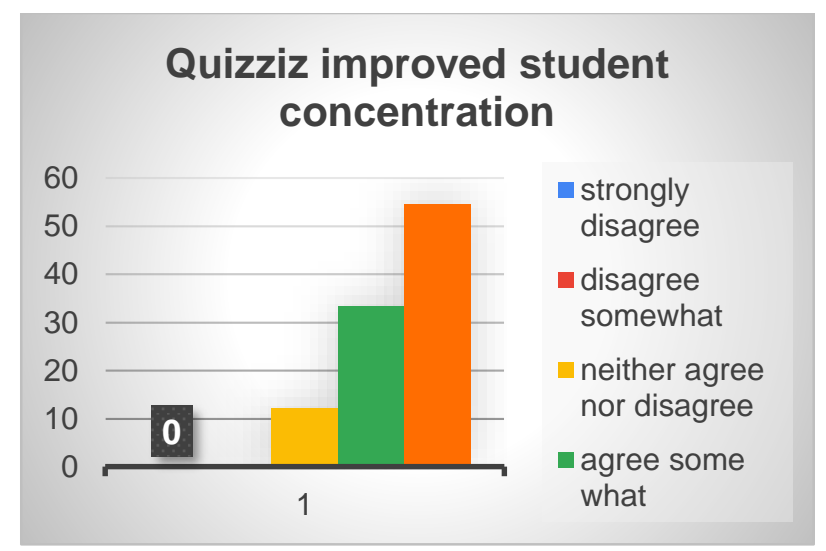

Figure 1. Survey result of Quizziz improved student concentration

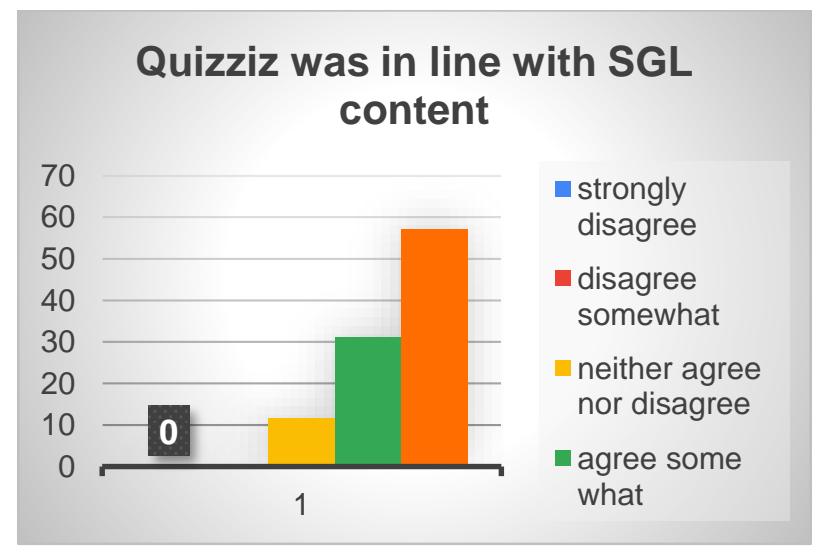

Figure 2 Survey result about Quizziz relevant with SGL content

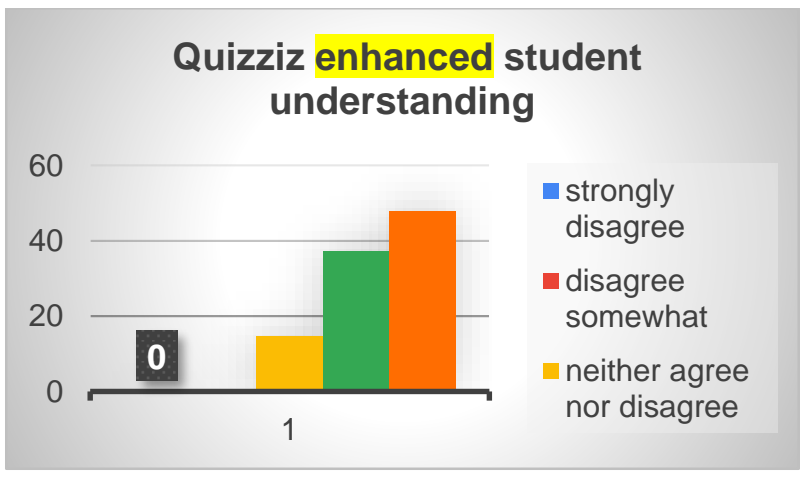

Figure 3. Survey result in Quizziz improve student's understanding

\section{DISCUSSION}

In this research, we found that the mean pre-test value was 54.93 ( $\mathrm{SE} \pm 1.448$ ), and the mean post-test value was 88.64 ( $\mathrm{SE} \pm 1.141$ ). Since the data distribution was normal, the statistical analysis was carried on through a paired T-test and obtained the p-value $<0.001$. This result means there was a significant difference in Quizziz's score before and after SGL activity, so we can conclude that SGL significantly improves student knowledge. This result is similar to the results reported by Hadimani, who studied the effectiveness of biochemistry learning in medical students using small groups.[8] Likewise, in line with Phenwan's research, the study found that pre-clinic students can get good scores on evidence-based medicine by learning in small groups. [9]

As a result of the Covid19 pandemic, there has been a change in the education system from offline to online using online applications, and Quizziz is one of them. The advantages of online learning appear in Namara D Mac et al. which concluded that online students incredibly showed an increase in the learning process both value and progress than those studied offline.[10]

Several studies have utilized Quizziz to evaluate the effectiveness of teaching and learning activities at all levels of education and various subjects. Purba et al. in 2019 employed Quizzis to assess the efficacy of teaching and learning activities in biochemistry courses.[11] Meanwhile, Hendarto et al. researched the use of quizzes in Nahwu science learning.[12]

The Quizziz application's advantages are free gamebased learning, easy to create a multiplayer, and can be used on any device, such as laptops, smartphones, or tablets. After completing the Quizziz questions, students can see their rank on the ranking board [11]. So, this application is also able to motivate and engage students or users with the content.[13]

According to the survey results, $88.3 \%$ of medical profession's students approved that the Quizziz questions were relevant to the SGL material, $87.9 \%$ of students stated that Quizzis helped increasing concentration, and $85.3 \%$ of students stated that Quizziz assisted them in 
understanding the SGL subject. Hendarto et al.'s study also obtained a similar result, in which $100 \%$ of participants perceived the Quizziz application's benefits in increasing their learning material comprehension.[12] Fang Zhou in 2020 has confirmed that the Quizziz application helped the learning process and enhanced students' interest in lessons. Even some students explained that the Quizziz application facilitated them to get used to answering questions, so they were not worried about undergoing exams.[7] Meanwhile, Purba (2019) found that the quizziz application can boost student concentration and motivation in studying physical chemistry courses.[11] Sou et al. also found that Quizziz raises student concentration in learning the Arabic language.[14]

\section{REFERENCES}

[1] Standar Nasional Pendidikan Profesi Dokter Indonesia. Standar Pendidikan Profesi Dokter Indonesia. Kons Kedokt Indones Indones. 2019;169.

[2] Purba Lsl. Peningkatan Konsentrasi Belajar Mahasiswa Melalui Pemanfaatan Evaluasi Pembelajaran Quizizz Pada Mata Kuliah Kimia Fisika I. J Din Pendidik. 2019;12(1):29.

[3] Boulden Dc, Hurt Jw, Richardson Mk. Implementing Digital Tools To Support Student Questioning Abilities: A Collaborative Action Research Report Implementing Digital Tools To Support Student Questioning Abilities A Collaborative Action Research Report. 2017;9(1).

[4] Agustina L, Rusmana Im. Pembelajaran Matematika Menyenangkan Dengan Aplikasi Kuis Online Quizizz. Pros Semin Nas Mat Dan Pendidik Mat Sosiomadika [Internet]. 2019;1-7. Available From: Http://Journal.Unsika.Ac.Id/Index.Php/Sesioma dika

[5] Pahamzah J, Syafrizal S. Quizizz As A Students' Reading Comprehension Learning Media: A Case Study At The Eleventh Grade Of Dwi Putra Bangsa Vocational School In Cimanggu. Int J English Lang Linguist Res. 2020;8(5):27-33.

[6] Hastjarjo Td. Rancangan Eksperimen-Kuasi. Bul
In medical education, Dayal et al. conducted research that used Quizziz to upgrade student understanding of musculoskeletal system anatomy and found a positive result. [15] As far as we know, our study is the first study using Quizziz to assess the effectiveness of teaching and learning activities in medical students of professional programs. We found that using the Quizziz application in SGL activities provides many positive benefits in increasing professional program students' competencies.

\section{CONCLUSIONS}

Small-Group learning activity in the medical profession program effectively enhances student knowledge evaluated by Quizziz application.

Psikol. 2019;27(2):187.

[7] Zhao F. Using Quizizz To Integrate Fun Multiplayer Activity In The Accounting Classroom. Int J High Educ. 2019;8(1):37-43.

[8] Hadimani Cp. Effectiveness Of Small Group Discussion Sessions In Teaching Biochemistry For Undergraduate Medical Students. 2014;8(1):77-81.

[9] Phenwan T. A Small Group Learning For Evidence-Based Medicine In Pre-Clinical Medical Students. Mededpublish. 2017;1-12.

[10] Namara D Mac, Murphy L. Online Versus Offline Perspectives On Gamified Learning. 2017;47-52.

[11] Purba Lsl. The Effectiveness Of The Quizizz Interactive Quiz Media As An Online Learning Evaluation Of Physics Chemistry 1 To Improve Student Learning Outcomes. J Phys Conf Ser. 2020;1567(2).

[12] Ch H. Analysis Of The Need For Quizizz-Based Nahwu Learning Application Model In Arabic Education Study Program, State University Jakarta. J Int Semin Lang Lit Art Educ [Internet]. 2020;2(2):109-22. Available From: Http://Journal.Unj.Ac.Id/Unj/Index.Php/Isllae

[13] Amornchewin R. The Development Of SQL Language Skills In Data Definition And Data Manipulation Languages Using Exercises With Quizizz For Students' Learning Engagement. 
Iggie (Indonesian J Informatics Educ. 2018;2(2):83.

[14] Yan S, Adam Z. Implementing Quizizz As Game-Based Learning In The Arabic Classroom Implementing Quizizz As Game-Based Learning
In The Arabic Classroom. 2018;(March).

[15] Dayal M, Green H, Browne C. Flipping Human Anatomy Lectures: Engaging Students Using Digital Media And Mini Lectures. 2016;15(November):2016. 